\title{
ANALISIS PENGARUH SITUASI, PRODUK, INDIVIDU PADA PERILAKU MEMBELI DAN MENGKONSUMSI MAKANAN RINGAN
}

\author{
Rita; Son Wandrial; Regina Inderadi \\ Management Department, School of Business Management, BINUS University \\ Jln. K.H. Syahdan No.9, Palmerah, Jakarta Barat 11480 \\ rita_edula@yahoo.co.id; sonwandrial@binus.ac.id; regina@binus.ac.id
}

\begin{abstract}
The study of consumer behavior is expected to receive more academic attention from scholars. The important aspects in consumer behavior are purchasing and consumption behavior by individuals. Purchasing and consumption behavior is influenced by situation, product and person. The objectives of this research are to examine main and interaction effects of consumption situation, snack products, and individual characteristics on purchasing and consumption behavior. This research was conducted in Jakarta using 218 respondents that has purchased and consumed snack products which were offered by researcher. The situation used in this research is consumption situation based on tasks definition, which the consumer purchases and consumes products based on purpose and objectives of purchases and consumption contetxs. Whereas individual characteristics used is observable characteristics such as age, gender, and level of education. Thus, the result show that individual characteristics based on age will interact with consumption situation and snack products which influence purchasing and consumption behavior. This is a fully model which influence purchasing and consumption behavior. The pattern of variance light /salty/ crispy snack, baby boomer and informal serving situation is the highest contribution to influence purchasing and consumption behavior.
\end{abstract}

Keywords: individual characteristics, consumption situation, snack products, purchasing and behavior

\begin{abstract}
ABSTRAK
Ilmu mengenai perilaku konsumen diharapkan mendapat lebih banyak perhatian dari sisi akademik untuk diselidiki. Aspek penting dari perilaku konsumen adalah perilaku pembelian dan pengkonsumsian oleh individu. Perilaku pembelian dan pengkonsumsian dipengaruhi oleh situasi, produk dan individu. Sasaran penelitian ini adalah untuk menguji pengaruh langsung dan/atau pengaruh bersama situasi konsumsi, produk makanan ringan, dan karakteristik individu pada perilaku membeli dan mengkonsumsi. Penelitian ini dilakukan di Jakarta dengan menggunakan 218 responden yang pernah membeli dan mengkonsumsi produk makanan ringan yang ditawarkan oleh peneliti. Situasi yang digunakan adalah situasi konsumsi berdasarkan definisi tugas dimana konsumen membeli dan mengkonsumsi produk berdasarkan maksud dan tujuan dari kondisi pembelian dan pengkonsumsian yang diinginkan. Sedangkan karakteristik individu yang digunakan adalah karakteristik yang mudah diamati seperti usia, jenis kelamin, dan tingkat pendidikan. Dengan demikian, hasil penelitian ini menunjukkan bahwa karakteristik individu berdasarkan usia berinteraksi dengan situasi konsumsi dan produk makanan ringan, sehingga mempengaruhi perilaku membeli dan mengkonsumsi. Hal ini merupakan model secara keseluruhan yang mempengaruhi perilaku membeli dan mengkonsumsi. Pola perbedaan makanan ringan asin/gurih/kering, baby boomer, dan situasi pelayanan merupakan kontribusi tertinggi untuk mempengaruhi perilaku membeli dan mengkonsumsi.
\end{abstract}

Kata kunci: karakteristik individu, situasi konsumsi, produk makanan ringan, perilaku membeli dan mengkonsumsi 


\section{PENDAHULUAN}

Dewasa ini perilaku konsumen semakin kompleks dan keterlibatan konsumen dalam membeli dan mengkonsumsi produk, tidak hanya sekedar sebagai rutinitas melainkan berdasar pada situasi. Maka tidak mengherankan, jika kini pemasar berusaha untuk menarik keterlibatan konsumen pada pembelian dan pengkonsumsian produk tertentu berdasar pada situasi tertentu pula. Untuk hal tersebut pemahaman mengenai perilaku konsumen akan sangat menunjang kesuksesan dalam mengelola strategi pemasaran.

Ketiga faktor dalam proses pengambilan keputusan pembelian dan pengkonsumsian melibatkan situasi, produk dan individu. Faktor-faktor tersebut menjadi sumber yang mempengaruhi perilaku. Perbedaan situasi, produk dan individu akan mempengaruhi perilaku konsumen dalam membeli dan mengkonsumsi. Oleh karena itu, menganalisis sumber-sumber yang dapat mempengaruhi perilaku pembelian dan pengkonsumsian sangat penting bagi pemasar untuk dapat mencapai kesuksesan dalam menciptakan, mengembangkan, serta mengelola setiap strategi yang ditawarkan.

Situasi dapat dikatakan terdiri dari waktu dan tempat tertentu yang dipakai oleh satu atau lebih orang dalam mengidentifikasi situasi terhadap kepentingan potensial (Belk, 1975b). Situasi merupakan kondisi sementara atau setting yang terjadi dalam lingkungan pada waktu dan tempat tertentu (Assael, 1998). Pemasar dalam mengembangkan strateginya harus berusaha memahami asal usul faktor situasi yang mempengaruhi konsumen dan mengarah pada keputusan pembelian dan pengkonsumsian yang diinginkan. Assael (1998) mengemukakan tiga tipe situasi yang mempengaruhi konsumen dalam pengambilan keputusan yaitu situasi konsumsi, situasi pembelian, dan situasi komunikasi. Sedangkan Belk (1975b) mengembangkan karakteristik situasi menjadi lima yaitu: lingkungan fisik, lingkungan sosial, perspektif waktu, definisi tugas, dan mood.

Produk merupakan variabel situasi yang dapat mempengaruhi perilaku pembelian dan pengkonsumsian. Goldsmith et. al. (1995) membagi produk menjadi dua jenis yaitu produk yang memiliki keterlibatan rendah dan keterlibatan tinggi. Homer dan Kahle (1988) dalam Goldsmith et al (1995) mengatakan bahwa produk keterlibatan rendah adalah produk-produk makanan natural seperti makanan ringan. Sedangkan produk-produk yang termasuk dalam keterlibatan tinggi yaitu: pakaian, pengkonsumsian media masa dan kepariwisataan (Goldsmith et. al., 1993; Becker dan Conner, 1981; Madrigal, 1992 dalam Goldsmith et. al., 1995).

Individu bertindak sebagai pembeli dan pengkonsumsi. Mereka membeli dan mengkonsumsi produk tertentu dalam situasi yang diinginkan. Dengan kata lain, individu dapat merespon setiap rangsangan yang mempengaruhi perilaku mereka dalam membeli dan mengkonsumsi. Salah satu yang mewakili individu adalah karakteristik individu itu sendiri. Belk (1975a) membagi karakteristik individu menjadi 2 (dua) jenis yaitu karakteristik yang mudah diamati seperti usia, jenis kelamin, pendidikan dan karakteristik yang sulit diamati seperti kecerdasan dan kepribadian.

Beberapa penelitian telah dilakukan untuk menguji dan menganalisis mengenai peran ketiga sumber dalam mempengaruhi perilaku pembelian dan pengkonsumsian. Penelitian-penelitian ini berusaha untuk mengukur pentingnya perbedaan situasional dalam perilaku dengan menggunakan persediaan perbedaan keprilakuan. Beberapa penelitian telah mengembangkan persediaan situasi mengenai beberapa jenis produk seperti: respon kegelisahan, respon permusuhan, pilihan aktivitas waktu luang, pilihan pengkonsumsian minuman (Endler dan Hunt, 1966, 1969; Endler et. al., 1962; Bishop et. al., 1970; Sandell, 1968 dalam Belk, 1974a). Produk-produk ini mempunyai karakteristik situasi tertentu dan berpengaruh pada perilaku konsumen dalam membeli dan mengkonsumsi. Namun hasil penelitian ini menemukan bahwa terdapat kontribusi perbedaan yang kecil dari situasi dan subjek sebagai main effect dan perbedaan yang besar dari pilihan alternatif (produk) dan bentuk interaksinya. Begitu juga, penelitian lain mengembangkan persedian situasi mengenai: minuman, aktivitas 
kesenangan, makanan ringan, makanan siap saji (Sandell, 1968a; Bishop dan Witt, 1970; Belk, 1974b, 1975a; Lutz dan Kakkar, 1975 dalam Belk,1975b).

Penelitian yang dilakukan oleh Goldsmith e.t al. (1995) menjelaskan juga bahwa variabel individu dan nilai sosial merupakan variabel penting yang mempengaruhi sikap dan perilaku. Mehrabian dan Russell (1976) mengemukakan bahwa orang akan merespon dan menghasilkan perbedaan dalam perilaku tidak hanya dilihat dari pengaruh masing-masing variabel lingkungan namun dilihat dari adanya interaksi dengan variabel lingkungan lainnya. Kardes (2002) mengatakan bahwa keputusan pembelian dan pengkonsumsian dipengaruhi oleh individu, situasional dan interaksi antara situasional dan individu.

Berdasarkan penelitian yang telah dilakukan oleh beberapa peneliti sebelumnya mengenai pengaruh situasi, produk dan karakteristik individu pada perilaku konsumen dalam membeli dan mengkonsumsi, maka simpulan yang dapat ditarik adalah peranan ketiga sumber dalam pengambilan keputusan sangat berguna bagi pemasar sebagai dasar pengembangan strategi bisnis.

Dengan adanya beberapa literatur dan penelitian yang menjelaskan mengenai ada dan/atau tidaknya pengaruh langsung maupun bersama-sama dari ketiga sumber yaitu situasi, produk dan karakteristik individu pada perilaku pembelian dan pengkonsumsian, maka penelitian ini menguji mengenai situasi konsumsi, produk makanan ringan, dan karakteristik individu (usia, jenis kelamin, dan tingkat pendidikan) sebagai pengaruh langsung (main effect) dan/atau pengaruh bersama (interaction effect) pada perilaku konsumen dalam membeli dan mengkonsumsi.

Produk yang digunakan adalah produk makanan ringan yang diadopsi dari penelitian Belk (1974a) yang mana merupakan produk convinience good yang memiliki keterlibatan rendah dari konsumen. Peneliti menggunakan produk makanan ringan karena produk yang memiliki keterlibatan rendah biasanya tidak memiliki pengaruh situasi dalam proses membeli dan mengkonsumsi. Namun penelitian yang dilakukan oleh Belk (1974a) mengatakan bahwa pembelian dan pengkonsumsian produk makanan ringan dipengaruhi oleh situasi. Produk-produk yang ditawarkan antara lain: potato chip, popcorn, biskuit, crakers, es krim, buah segar, sandwich, keju, kacang dan pastry.

Situasi yang digunakan dalam penelitian ini juga diadopsi dari penelitian Belk (1974a) dan dikembangkan sendiri oleh peneliti yaitu situasi konsumsi berdasarkan definisi tugas. Situasi ini merupakan situasi ketika konsumen membeli dan mengkonsumsi produk untuk tujuan atau maksud tertentu. Dengan kata lain, produk dibeli dan dikonsumsi oleh diri sendiri maupun orang lain dalam situasi tertentu. Karakteristik individu yang digunakan untuk merespon situasi konsumsi dan produk makanan ringan adalah karakteristik demografi. Karakteristik demografi merupakan karakteristik fisik yaitu jenis kelamin, usia dan tingkat pendidikan yang mana karakteristik ini merupakan karakteristik individu yang mudah diamati. Peneliti menggunakan karakteristik individu berdasar demografi karena Goldsmith et. al. (1995) mengemukakan bahwaadanya pengaruh faktor demografi dalam membeli dan mengkonsumsi produk-produk yang memiliki keterlibatan rendah seperti makanan ringan walaupun terkadang tidak terbukti.

Selain itu, penelitian ini menggunakan metode analisis of variance (anova) sebagai alat analisis untuk memahami interaksi yang terjadi dalammempengaruhi perilaku membeli dan mengkonsumsi. Selain itu, respondenyang digunakan dalam penelitian ini adalah konsumen yang mengkonsumsi minimal salah satu produk yang ditawarkan oleh peneliti dan berlokasi di Jakarta. Penelitian ini diharapkan dapat mengembangkan wawasan mengenai sumber-sumber yang mempengaruhi perilaku konsumen dalam membeli dan mengkonsumsi makanan ringan sehingga peranan situasi, produk dan karakteristik individu dalam pengambilan keputusan pembelian dan pengkonsumsian oleh konsumen dapat digunakan oleh pemasar sebagai dasar pertimbangan dalam mengembangkan strategi bisnis untuk keunggulan kompetitif perusahaan. 
Penelitian ini berusaha menjawab dua pertanyaan rumusan penelitian yaitu: (1) Apakah situasi konsumsi, produk makanan ringan dan karakteristik individu (usia, jenis kelamin, tingkat pendidikan) berpengaruh secara langsung (maineffect) pada perilaku membeli dan mengkonsumsi? (2) Apakah situasi konsumsi, produk makanan ringan dan karakteristik individu (usia, jenis kelamin, tingkat pendidikan) berpengaruh secara bersama-sama (interaction effect) pada perilaku membeli dan mengkonsumsi?

Penelitian ini bertujuan untuk menguji dan menganalisis mengenai: (1) Apakah situasi konsumsi, produk makanan ringan dan karakteristik individu berpengaruh secara langsung (main effect) pada perilaku membeli dan mengkonsumsi? (2) Apakah situasi konsumsi, produk makanan ringan dan karakteristik individu berpengaruh secara bersama-sama (interaction effect) pada perilaku membeli dan mengkonsumsi?

\section{Tinjauan Pustaka}

\section{Pengertian Perilaku Konsumen}

Perilaku konsumen merupakan proses keputusan dan aktivitas fisik yang dilakukan oleh individu ketika mengevaluasi, mendapatkan, dan menggunakan atau menentukan barang dan jasa (Loudon dan Bitta, 2001). Individu merupakan konsumen yang mengidentifikasi kebutuhan dankeinginannya, membuat keputusan pembelian dan menentukan produk selama proses mengkonsumsi (Solomon, 2002). Perilaku konsumen sebagai aktivitas-aktivitas secara langsung melibatkan cara memperoleh (obtaining), mengkonsumsi (consuming) dan membuang (disposing) produk dan jasa termasuk proses pengambilan keputusan yang mendahului dan mengikuti tindakantindakan tersebut (Engel et. al., 1995 dalam Arditya, 2010).

Perilaku konsumen sebagai studi mengenai individu, kelompok, atau organisasi dan proses yang mereka gunakan untuk memilih, mengamankan, menggunakan dan membuang produk, jasa dan pengalaman atau ide-ide guna memuaskan kebutuhan dan pengaruh proses ini terhadap konsumen dan (Hawkins, Best dan Coney, 1999 dalam Arditya, 2010). Pengertian ini lebih mengarahkan untuk memeriksa pengaruh tidak langsung dari keputusan konsumen dan konsekuensinya yang tidak hanya melibatkan pihak penjual dan pembeli, tetapi juga masyarakat pada umumnya.

\section{Perilaku Membeli dan Mengkonsumsi}

Proses pembelian dan pengkonsumsian merupakan pertukaran secara fisik biasanya dalam bentuk simbolik seperti uang untuk produk atau jasa yang dapat memuaskan beberapa kebutuhan manusia (Csikszentmihalyi, 2000). Dengan kata lain, membeli dan mengkonsumsi didefinisikan sebagai perilaku untuk kesejahteraan yang ditingkatkan dalam pertukaran exixtensial atau experiental rewards. Existensial reward berhubungan dengan memuaskan kebutuhan yang ditulis oleh Maslowian (bertahan hidup dan keamanan, kasih sayang, serta penghargaan dan aktualisasi diri). Sedangkan experiental reward lebih menunjukkan peningkatan sementara dalam positive mood dari pengalaman orang ketika mereka bertindak dalam tujuan yang telah ditentukan.

Perilaku pembelian dan pengkonsumsian berbagai jenis produk dapat diukur dengan menggunakan seberapa sering konsumen membeli dan menggunakan setiap produk tersebut (Goldsmith et. al., 1995). Sebelum mengukur frekuensi konsumen membeli dan mengkonsumsi setiap produk maka pemasar perlu memahami proses pembelian dan pengkonsumsian yang dilakukan oleh individu sebagai konsumen serta tindakan apa yang perlu dilakukan oleh pemasar agar dapat mempertahankan konsumen mereka. Oleh karena itu, pemasar perlu memperhatikan dua perspektif mengenai tahapan konsumen dalam membeli dan mengkonsumsi yaitu perspektif konsumen dan perspektif pemasar. 


\section{Model Perilaku Konsumen}

Assael (1998) menggambarkan model perilaku konsumen yang menjelaskan mengenai 3 (tiga) kemungkinan yang mempengaruhi perilaku dan pengkonsumsian yaitu konsumen, pengaruh lingkungan dan strategi pemasaran. Faktor pertama yang mempengaruhi perilaku konsumen adalah konsumen secara individual dimana digambarkan dengan kebutuhan, persepsi karakteristik mereka, dan sikap yang mengarah pada alternatif yang dapat mempengaruhi pilihan merek. Selain itu, karakteristik demografi, gaya hidup, kepribadian juga dapat mempengaruhi pilihan terhadap merek.

Faktor kedua adalah lingkungan yang terbagi menjadi dua yaitu pertama, lingkungan yang diwakili oleh budaya (norma dan nilai sosial), sub budaya (bagian dari asosiasi dengan perbedaan norma dan nilai dalam hal tertentu), dan kelompok tatap muka (anggota keluarga, teman, kelompok acuan). Kedua, lingkungan yang diwakili oleh organisasi pemasar yang menyediakan penawaran yang dapat memuaskan kebutuhan konsumen khususnya dalam bentuk strategi pemasaran yang dimiliki. Tiga kemungkinan ini merupakan faktor yang mempengaruhi perilaku konsumen dalam membuat keputusan pembelian, yang sering disebut sebagai consumer respon.

\section{Faktor-Faktor yang Mempengaruhi Perilaku Konsumen}

Proses pilihan konsumen terhadap barang atau jasa yang ditawarkan diawali pada saat konsumen menerima beberapa rangsangan yang mempengaruhinya. Proses pilihan konsumen ini dipengaruhi oleh karakteristik produk atau jasa, karakteristik konsumen serta lingkungan. Strategi perusahaan perlu mendasari keputusannya pada beberapa hal yang mempengaruhi proses pengambilan keputusan membeli dan mengkonsumsi dalam perilaku konsumen. Arditya (2010) mengatakan bahwa terdapat berbagai faktor yang mempengaruhi proses pengambilan keputusan pembelian produk yang berimplikasi pada adanya perbedaan perilaku tiap individu dalam usaha memenuhi kebutuhan dan keinginannya.

Penelitian mengenai perilaku konsumen memerlukan tiga faktor yang menentukan perilaku pembelian dan pengkonsumsian (Belk, 1974b) yaitu: yang relevan, objek yang digunakan untuk situasi tersebut dan orang yang bertindak sebagai responden.

\section{Faktor Individu dalam Perilaku Membeli dan Mengkonsumsi}

Personality secara psikologi mempelajari individu dalam tiga bentuk kerangka kerja yang saling berhubungan yang mana memiliki level ofanalysis yang seringkali overlap (McAdam. 1996; 2001 dalam Baumgartner, 2002). Tiga kerangka kerja ini meliputi: level pertama, personality traits berhubungan dengan karakteristik individu yang berlainan secara situasionaldan bersifat sementara yang mana membedakan perbedaan individu dan menunjukkan kekonsistenan dalam perilaku sepanjang situasi dan berkelanjutan. Level kedua, personal concern berhubungan dengan tujuan yang akan dilakukan orang dan strategi yang mereka gunakan untuk mencapai tujuan tersebut. Individu didefinisikan lebih sempit dalam bentuk konstruk tindakan seperti individu project, individu striving dan task life (Little, 1989, 1996; Emmons, 1989; Cantor, 1990 dalam Baumgartner, 2002). Level ketiga, individu dalam bentuk cerita kehidupan (task life) berhubungan dengan narasi yang mana konstruk orang untuk mengintegrasikan ingatan mereka di masa lalu, pengalaman saat ini, dan masa depan yang diantisipasi dalam keseluruhan yang saling berhubungan dan untuk mengembangkan identitas yang mana memberikan pengertian dan tujuan untuk kehidupan mereka.

\section{Karakteristik Individu dari Sisi Demografi}

Jenis kelamin akan memberikan dampak pada perilaku pembelian dan pengkonsumsian (Jasper dan Lan, 1992; Slama dan Tashlian, 1985; Zithhaml, 1985 dalam Homburg dan Giering, 2011), Perilaku membeli wanita lebih kuat dipengaruhi oleh evaluasi mereka dari proses interaksi 
individu. Dengan kata lain, wanita lebih terlibat dalam aktivitas pembelian (Slama dan Tashlian, 1985 dalam Homburg dan Giering, 2011). Moscovitch (1982); Roedder John dan Cole (1986); Smith dan Batles (1990); Walsh (1982) dalam Homburg dan Giering (2011) mengatakan bahwa usia muda dan lebih tua mempengaruhi perilaku pembelian dan pengkonsumsian dalam hal kemampuan mereka mengevaluasi produk.

\section{Faktor Lingkungan dalam Perilaku Pembelian dan Pengkonsumsian}

Variabel lingkungan mampu menjelaskan dan meramalkan perilaku (Russell dan Mehrabian, 1976). Perilaku konsumen merupakan fungsi dua kelas variabel lingkungan yang berbeda yaitu pertama, lingkungan yang segala sesuatunya berada diluar orang yang perilakunya dijelaskan sehingga dapat diukur secara bebas dari orang tersebut, termasuk objek yang dibeli dan setting dalam kasus perilaku konsumen. Kedua, lingkungan yang menggambarkan perbedaan dalam orang (apapun yang orang bawa ke lingkungan dan dapat diukur secara bebas dari lingkungan).

\section{Situasi Konsumen dalam Keputusan Pembelian dan Pengkonsumsian}

Secara umum, Srivastava (1981) mengkonseptualisasikan dua pendekatan untuk mengembangkan taxonomy situasional pada proses pilihan konsumen yaitu: pertama, psychological approach merupakan pendekatan yang mengklasifikasikan situasi kedalam proses psikologi yang akan diarahkan. Keuntungan pendekatan ini berfokus pada situasi penerimaan oleh individu. Pendekatan ini memiliki dampak sistematik yang rendah pada pilihan konsumen. Kedua, objective situation approach merupakan pendekatan yang menggambarkan lebih baik mengenai perilaku konsumen. Pendekatan ini lebih berhubungan dengan produk yang digunakan, dan merupakan faktor eksternal untuk konsumen yang mengarah pada perbedaan perilaku individu. Dari dua pendekatan ini dapat ditarik simpulan bahwa dalam mengembangkan rule of thumb yang sederhana, peneliti bidang pemasaran harus memiliki kesepakatan dengan situasi yang komplek sehingga perbedaan pilihan konsumen yang mengarah pada perilaku pembelian dapat dianalisis.

Keterlibatan individu terdiri dari tiga perspektif yaitu product centered, subject-centered, dan response-centered (Finn, 1983 dalam Broderick dan Muller, 2004). Dalam hal ini subject-centered lebih ditekankan. Perspektif subject-centered berguna untuk menyediakan kerangka dalam memahami perilaku konsumen secara individu dan penerapannya dalam segmentasi pasar. Selain itu, perspektif subjectcentered bahwa konsumen berbeda secara individu dalam bentuk keterlibatan yang berhubungan dengan tipe variabel.

\section{Faktor Produk dalam Keputusan Pembelian dan Pengkonsumsian}

Produk merupakan bagian yang mempengaruhi perilaku konsumen dalam membeli barang dan jasa yang biasanya termasuk ke dalam strategi perusahaan. Produk didefinisikan sebagai sesuatu yang dapat ditawarkan ke pasar untuk memuaskan kebutuhan dan keinginan (Kotler, 2012). Produk yang dipasarkan terdiri dari barang-barang berwujud, jasa, pengalaman, peristiwa, orang, properti, organisasi, informasi dan ide.

\section{Konsumen, Situasi Konsumsi dan Produk dalam Mempengaruhi Perilaku}

Bagaimana orang berperilaku bergantung pada tujuan yang berlaku bagi mereka dalam situasi, persepsi terhadap struktur reward yang diberikan oleh lingkungan dan persepsi mengenai kemampuan untuk berperilaku dalam berbagai cara (Price, 1974; Price dan Bouffard, 1974; Rotter, 1954; Bandura, 1986 dalam Pervin,1989). Seperti yang telah dijelaskan sebelumnya bahwa situasi merupakan perbandingan mengenai waktu dan tempat yang dilengkapi oleh satu atau lebih banyak orang dalam mengidentifikasi situasi terhadap kepentingan potensial. Maka dengan mengadopsi paradigma S-O-R (Stimulus-Organism-Response) yang ditulis oleh Belk (1975b) mengatakan bahwa rangsangan (stimulus) dapat dibedakan menjadi faktor situasi dan faktor bukan situasi (produk). 


\section{Interaksi Situasi dan Individu Mempengaruhi Perilaku Konsumen}

Lewin (1935) dalam Endler dan Rosenstein (1997) mengatakan bahwa variabel individu dan situasi bukan keseluruhan variabel independen yang dapat dipertimbangkan sebagian, tetapi lebih merupakan variable independen yang saling berinteraksi. Interaksi individu dan situasi dan pencapaian motif dapat secara berbeda sehingga menghasilkan perbedaan orang dengan menggunakan situasi yang sesuai (Rosenstein, 1952 dalam Endler dan Rosenstein, 1997).

Hipotesis 1: Pengaruh bersama antara situasi konsumsi dan karakteristik individu pada perilaku membeli dan mengkonsumsi

\section{Interaksi Situasi dan Produk Mempengaruhi Perilaku Konsumen}

Assael (1998) mengatakan bahwa situasi dan produk digambarkan dalam bentuk prinsip kognitif dari konteks yang mana keadaan konsumen mengatur rangsangan ke dalam figure (bagian depan) dan ground (latar belakang) dengan membedakan rangsangan yang terlihat dan yang tidak terlihat. Dalam hal ini, situasi merupakan background dan produk merupakan figure.

Hipotesis 2: Pengaruh bersama antara situasi konsumsi dan produk pada perilaku membeli dan mengkonsumsi.

\section{Interaksi Produk dan Individu Mempengaruhi Perilaku Konsumen}

Motif konsumen dalam melakukan pembelian dan pengkonsumsian selalu berhubungan dengan produk sebagai objek dan situasi (Ratneshwar et. al., 1999). Aksioma dalam pemasaran adalah bahwa orang membeli sesuatu bukan untuk apa mereka membeli tetapi apa yang dapat mereka lakukan (Levitt, 1960; Zeithaml, 1988; Haley, 1968; Young dan Feigin, 1975 dalam Ratneshwar et. al., 1999). Aksioma ini secara signifikan berhubungan dengan perbedaan antara aspek interinsik yang mengacu pada produk dan jasa dan aspek yang mengacu pada serangkaian instrumen produk yang pada akhirnya lebih menunjukkan pada ciri, karakteristik atau atribut dan manfaat atau kriteria keputusan dari produk tersebut (Huffman dan Houston, 1993 dalam Ratneshwar et. al., 1999). Dengan demikian, penelitian mengenai pembelian dan pengkonsumsian produk makanan ringan saling berinteraksi dengan karakteristik individu. yang menggunakan faktor demografi seperti jenis kelamin, usia dan tingkat pendidikan.

Hipotesis 3: Pengaruh bersama antara produk dan karakteristik individu pada perilaku membeli dan mengkonsumsi.

\section{Interaksi Situasi, Produk dan Individu Mempengaruhi Perilaku Konsumen}

Assael (1998) mengadopsi paradigma S-O-R yang ditulis oleh Belk (1975b) menjelaskan bahwa situasi dan obyek (produk) tidak dibedakan menjadi dua rangsangan (stimulus) yang terpisah, tetapi rangsangan ini saling berinteraksi dalam mempengaruhi konsumen dan reaksi mereka. Oleh karena itu, dua pengaruh yang menguatkan tindakan konsumen adalah produk dan situasi. Konsumen akan memberikan reaksi pada produk dan situasi serta memutuskan merek yang akan dikonsumsi. Interaksi antara psychological set konsumen (kebutuhan, sikap dan preferensi), situasi, dan produk yang dihasilkan dalam proses pilihan menunjukkan perilaku konsumen. Dengan kata lain, ketiga variabel ini secara bersama-sama mempengaruhi perilaku pembelian yang dilakukan oleh konsumen. Dengan adanya interaksi atau pengaruh bersama antara situasi dan produk dan karakteristik individu mempengaruhi perilaku pembelian dan pengkonsumsian maka hipotesis yang dapat dikembangkan adalah:

Hipotesis 4: Pengaruh bersama antara situasi, produk dan karakteristik individu pada perilaku membeli dan mengkonsumsi. 


\section{METODE}

\section{Desain Penelitian}

Penelitian ini menggunakan metode survey yang merupakan sistem untuk mengumpulkan informasi secara luas dari sekumpulan subjek yang berkepentingan dalam berbagai bidang yang beraneka ragam (Fink, 2009). Penelitian ini dirancang untuk menjelaskan adanya interaksi yang terjadi dari sumber-sumber yang mempengaruhi perilaku membeli dan mengkonsumsi. Adapun sumbersumber yang mempengaruhi perilaku pembelian dan pengkonsumsian terdiri dari tiga sumber yaitu situasi, produk dan karakteristik individu. Jika ketiga sumber ini saling berinteraksi, maka akan mempengaruhi perilaku konsumen dalam membeli dan mengkonsumsi.

\section{Populasi dan Sampel Penelitian}

Populasi dalam penelitian ini adalah konsumen yang pernah membeli dan atau mengkonsumsi produk makanan ringan yang ditawarkan oleh peneliti yaitu potato chip, popcorn, biskuit, sandwich, keju, kacang, buah-buhan segar, es krim, pastry dan crackers. Sampel yang digunakan harus memiliki kriteria yaitu paling sedikit pernah membeli dan atau mengkonsumsi salah satu produk makanan ringan yang ditawarkan oleh peneliti, sehingga dapat mewakili populasinya.

Sampel yang digunakan adalah Pelajar SMP dan SMU Katolik Kristoforus, Mahasiswa Binus University pada School of Business and Management dan Mahasiswa Universitas Katolik Atmajaya, dimana keseluruhan sampel berlokasi di Jakarta. Penelitian ini mengambil setting di Jakarta karena merupakan salah satu kota besar yang diperkirakan bahwa perilaku pembelian dan pengkonsumsian suatu produk berhubungan dengan berbagai macam situasi.

\section{Metode Pengambilan Sampel}

Pengambilan sampel dilakukan secara non probability sampling dan menggunakan metode purposive sampling. Pengambilan sampel secara nonprobability sampling dimaksudkan bahwa dalam kerangka pengambilan sampel, setiap anggota tidak mempunyai kesempatan yang sama untuk diseleksi (Crask et. al., 1995). Sedangkan yang dimaksud dengan metode purposive sampling adalah metode pengambilan sampel yang memenuhi kriteria tertentu sebagai anggota sampel (Cooper dan Schindler, 2006).

Menurut Hair et. al., (1998) mengatakan bahwa ukuran sampel paling sedikit 50 responden atau yang paling baik adalah lebih dari 100 responden. Selain itu, ukuran sampel tidak lebih dari 500 responden (Sekaran, 2003). Dalam penelitian ini, sampel yang digunakan sebanyak 218 orang. Jumlah ini diperoleh dengan menyebarkan kuesioner sebanyak 250 orang, 32 kuesioner lainnya gugur karena responden tidak memberikan jawaban yang lengkap.

\section{Metode Pengumpulan Data}

Penelitian ini menggunakan metode survey dengan kuesioner yang berisi butir-butir pengukur konstruk atau variabel dalam penelitian, yang disampaikan pada responden untuk diisi. Di dalam kuesioner tersebut, peneliti menanyakan kepada responden mengenai identitas diri yang berupa usia, jenis kelamin dan pendidikan terakhir sebagai variabel karakteristik individu; mengenai kategori makanan ringan apa yang sering dibeli dan dikonsumsi oleh mereka terutama untuk produk-produk makanan ringan yang ditawarkan dan menanyakan mengenai kategori situasi yang sering dialami ketika membeli dan mengkonsumsi kategori makanan ringan yang mereka pilih tersebut. Selain itu, peneliti juga menanyakan mengenai seberapa sering mereka membeli dan mengkonsumsi kategori makanan ringan yang dipilih dalam kategori situasi yang sering dialami oleh mereka. 
Kuesioner utama ini digunakan untuk pengujian model terdiri dari setiap item pertanyaan yang dikembangkan oleh peneliti yang mana merupakan gabungan setiap item dari setiap variabel kategori situasi dan kategori produk yang diperoleh dari uji pendahuluan. Setelah responden menjawab setiap pertanyaan yang diberikan dan mengumpulkan kembali kuesioner tersebut, peneliti memberikan kenang-kenangan berupa gantungan kunci sebagai ucapan terima kasih atas partisipasi mereka pada penelitian ini. Selain itu, hadiah ini diberikan agar responden tidak mengalami kebosanan dalam menjawab setiap pertanyaan dan menjawab dengan keadaan sesungguhnya yang dialami oleh mereka.

\section{Uji Pendahuluan}

Uji pendahuluan ini dimaksudkan untuk menentukkan kategori produk makanan ringan dan kategori situasi yang digunakan dalam menguji model penelitian. Uji pendahuluan ini menggunakan sampel yaitu konsumen yang pernah membeli dan mengkonsumsi kesepuluh macam produk makanan ringan yang ditawarkan oleh peneliti yaitu potato chip, popcorn, biskuit, sandwich, keju, kacang, buah-buhan segar, es krim, pastry dan crackers.

Pengambilan sampel secara non probability sampling dan menggunakan metode purposive sampling. Usia sampel dibatasi mulai dari 13 tahun sampai dengan 51 tahun. Menurut Assael (1998), usia 13 tahun merupakan usia seorang remaja yang mulai mengerti dan memiliki tanggung jawab keluarga untuk memutuskan yang terbaik bagi dirinya dalam pembelian dan pengkonsumsian suatu produk. Sedangkan usia 51 tahun merupakan batas seseorang mulai mengalami penurunan dalam melakukan pembelian dan pengkonsumsian suatu produk. Alat analisis untuk melakukan uji pendahuluan dalam instrumen ini menggunakan metode exploratory factor analysis dan uji reliabilitas.

\section{Metode Exploratory Factor Analysis}

Sebelum menyebar kuesioner untuk melakukan pengkategorian situasi dan produk, peneliti melakukan wawancara dan mengirim e-mail sebanyak 50 orang teman di Jakarta mengenai daftar situasi konsumsi dan produk dalam membeli dan mengkonsumsi makanan ringan yang ditawarkan dalam penelitian ini. Daftar situasi dan produk yang ditawarkan ini, diperoleh dari penelitian exploratoryyang dilakukan oleh Belk (1974a). Dalam hal ini, peneliti hanya memastikan bahwa daftar pertanyaan mengenai situasi yang ditawarkan, relevan untuk masyarakat Jakarta dan produk-produk yang ditawarkan ini juga relevan menjadi kategori produk makanan ringan.

Setelah memperoleh hasil daftar situasi konsumsi dan produk maka terdapat 10 macam situasi konsumsi dan 10 macam produk makanan ringan yang digunakan dalam uji pendahuluan. Dari 10 macam situasi konsumsi dan 10 macam makanan ringan, peneliti melakukan pengkategorian situasi dan produk dalam membeli dan mengkonsumsi makanan ringan dengan menggunakan explolatory factor analysis.

Pengumpulan data untuk pengkategorian situasi konsumsi dan produk makanan ringan dengan metode faktor analisis dilakukan dengan menyebarkan kuesioner sebanyak 500 orang. Dalam menyebarkan kuesioner, peneliti dibantu oleh 4 (empat) orang teman yang sebelumnya diberikan petunjuk mengenai ciri makanan ringan yang ditawarkan dan proses pengisian kuesioner. Tingkat pengembalian kuesioner ini 100\% namun kuesioner ini mengalami kegagalan sebanyak 3,31\% yaitu sebanyak 16 orang yang disebabkan karena responden tidak lengkap dalam pengisian. Jadi total sampel yang digunakan untuk melakukan exploratory factoranalysisdalam menentukan kategori produk dan situasi adalah sebanyak484 orang $(96,69 \%)$. 


\section{Uji Reliabilitas}

Reliabilitas pengukuran mencerminkan apakah pengukuran terbebas dari kesalahan, sehingga memberikan hasil pengukuran yang konsisten pada kondisi yang berbeda dan pada masing-masing item dalam instrument (Sekaran, 2003). Konsistensi internal item-item pengukuran dalam kuesioner diuji dengan Cronbach Alpha dengan nilai lebih besar dari 0,7 meskipun nilai 0,6 masih dapat diterima (Hair et. al., 1998).

\section{Hasil Uji Exploratory Factor Analysis dan Uji Reliabilitas}

Tabel 1 Hasil Pengujian Exploratory Factor Analysis Variabel Produk

\begin{tabular}{|c|c|c|c|}
\hline \multirow{2}{*}{ Produk } & \multicolumn{3}{|c|}{ Komponen } \\
\hline & 1 & 2 & 3 \\
\hline POTATOCHIP & .621 & & \\
\hline POPCORN & .542 & & \\
\hline BISKUIT & .692 & & \\
\hline BUAHSEGAR & & & .857 \\
\hline SANDWICH & & .817 & \\
\hline PASTRY & & .801 & \\
\hline ESKRIM & & & .645 \\
\hline KEJU & & .530 & \\
\hline KACANG & .721 & & \\
\hline CRACKERS & .722 & & \\
\hline
\end{tabular}

Tabel 2 Hasil Pengujian Exploratory Factor Analysis Variabel Situasi Konsumsi

\begin{tabular}{lccc} 
& \multirow{2}{*}{ Situasi } & \multicolumn{3}{c}{ Komponen } \\
\cline { 2 - 4 } & $\mathbf{1}$ & $\mathbf{2}$ & $\mathbf{3}$ \\
\hline SIT1 & & & .876 \\
SIT2 & & .588 & \\
SIT3 & .852 & & \\
SIT4 & .845 & & \\
SIT5 & & .688 & \\
SIT6 & & .713 & \\
SIT7 & .579 & & \\
SIT8 & & .594 & \\
SIT9 & .519 & & \\
SIT10 & &
\end{tabular}

\section{Definisi Operasional dan Pengukuran Variabel}

Pada penelitian ini, variabel-variabel yang diteliti mengacu pada penelitian Belk (1974a), yaitu mengenai pengaruh kategori situasi konsumsi, kategori jenis produk makanan dan karakteristik individu pada perilaku pembelian dan pengkonsumsian makanan ringan. Adapun beberapa variable operasional dan pengukuran dalam penelitian ini terdiri dari variabel independen dan variabel dependen. Masing-masing variabel memiliki faktor-faktor sebagai berikut:

\section{Variabel Independen}

Faktor Situasional diukur dengan menggunakan skala nominal yang terbagi ke dalam tiga kategori yaitu: 1 = nutritive situation; 2 = planned situation, 3 = informal serving situation. Situasi nutritive (NS) merupakan situasi pembelian dan pengkonsumsian produk makanan ringan yang lebih 
menekankan pada diri individu sendiri. Situasi planned consumption (PS) merupakan situasi pembelian dan pengkonsumsian produk makanan ringan yang direncanakan untuk kebutuhan orang lain dan diri individu sendiri. Situasi informal serving (IS) merupakan situasi pembelian dan pengkonsumsian produk makanan ringan yang lebih menekankan pada orang lain bukan untuk dikonsumsi sendiri.

Faktor produk yang diukur dengan menggunakan skala nominal yang terbagi ke dalam tiga kategori yaitu $1=$ light/salty/crispy snack, $2=$ substantial snack, $3=$ sweet snack. Light/salty/crispy snack (LSC) merupakan jenis makanan ringan yang kebanyakan memiliki rasa asin/gurih/bentuknya kering. Contoh makanan ringan ini antara lain: potato chip, popcorn, kacang, crackers dan biskuit. Substantial snack (SSS) merupakan jenis makanan ringan yang dapat memberikan tambahan energi dan nutrisi tambahan pada tubuh untuk kegiatan sehari-hari. Kebanyakan bentuknya basah atau tidak crispy/kering. Contoh makanan ringan ini antara lain: sandwich, pastry, dan keju. Sweet snack (SWS) merupakan jenis makanan ringan yang digunakan untuk melepas dahaga dan menyegarkan. Kebanyakan jenis makanan ringan ini digunakan sebagai makanan penutup dan memiliki rasa manis. Contoh makanan ringan ini adalah: es krim dan buah-buahan segar.

Faktor individu diukur dengan menggunakan skala nominal. Dalam penelitian ini peneliti melihat individu dari sudut demografi yang terdiri dari tiga bagian yaitu: bagian pertama dilihat dari sudut pandang jenis kelamin yang terbagi ke dalam 2 kategori yaitu $1=$ pria $(\mathrm{P})$ dan $2=$ wanita $(\mathrm{W})$. Bagian kedua dilihat dari sudut pandang usia yang dibagi menjadi 3 kategori yaitu $1=$ teens $(\mathrm{TN}=$ usia 13 tahun sampai dengan 19 tahun), 2 = babybusters ( $\mathrm{BR}=$ usia 20 tahun sampai dengan 32 tahun) dan 3 = baby boomers $(\mathrm{BB}=$ usia 33 tahun sampai dengan 51 tahun). Bagian ketiga dilihat dari sudut pandang latar belakang pendidikan terakhir yang dibagi menjadi 3 kategori yaitu: $1=$ SMP, $2=$ SMA, dan 3 = Diploma/Universitas (DPT).

\section{Variabel Dependen}

Perilaku pembelian dan pengkonsumsian mencerminkan frekuensi yang dilakukan oleh konsumen dalam membeli dan mengkonsumsi kategori produk makanan ringan yang dipilih dalam kategori situasi konsumsi yang dipilih juga. Perilaku pembelian dan pengkonsumsian ini diukur dengan menggunakan skala likert dengan rentang poin 1 sampai dengan 5, $1=$ sangat tidak sering dan $5=$ sangat sering.

\section{Uji Homogeneity of Variance}

Uji homogeneity of variance merupakan uji asumsi untuk melakukan analisis ANOVA yang menunjukkan bahwa variabel dependen memiliki varians yang sama dalam setiap kategori variabel independent (Ghozali, 2001). Jika terdapat lebih dari satu variabel independen, maka harus ada homogeneity of variance dalam cell yang dibentuk oleh variabel independen kategorikal. Uji homogeneity of variance diperlukan juga jika jumlah kasus dalam setiap sel berbeda (Norusis, 2002). Uji homogeneity of variance menggunakan SPSS versi 10 dengan nama levene's test of homogeneity of variance. Kriteria pengujian ini yaitu nilai levene test diatas 5\%, maka hipotesa nol akan diterima berarti bahwa rata-rata kelompok memiliki variance yang sama, sebaliknya jika nilai levene test dibawah 5\% maka hipotesa nol ditolak sehingga rata-rata kelompok memiliki variance yang berbeda.

Penyebaran data yang tidak homogen disebabkan oleh pengambilan sampel yang tidak random pada masing-masing sel dalam populasi sehingga rata-rata sampel berbeda dari populasinya. Jika hal ini terjadi sebaiknya dilakukan transformasi data dalam bentuk logaritma agar data mendekati normal/variance sama (Huck, 2000). Akan tetapi jika variance kelompok masih berbeda, maka Box (1954) dalam Ghozali (2001) mengatakan bahwa analisis data menggunakan Anova masih dapat dilanjutkan karena anova robust untuk penyimpangan yang kecil dan moderat dari homogeneity 
ofvariance yaitu harus 3 atau kurang dari 3. Apabila asumsi homogeneity of variance dilanggar maka sebaiknya menggunakan prosedur multiple comparison yang mana tidak mengasumsikan kesamaan varian dan prosedur ini digunakan jika jumlah kasus tiap sel berbeda (Norusis, 2002).

\section{Analysis of Variance (ANOVA)}

Merupakan metode untuk mengkaji hubungan antara satu variable dependen yang berbentuk metrik dengan satu atau lebih variabel independen yang berbentuk non-metrik atau kategorial (Ghozali, 2001). Selain itu, secara umum prosedur analysis of variance digunakan untuk menguji hipotesa nol dengan menggunakan kriteria pengujian yaitu F test atau probabilitas. Santoso (2005) dan Huck (2005) mengatakan bahwa Jika $\alpha<0.05$ maka hipotesa nol akan ditolak yang berarti bahwa ratarata kategori variabel independen tidak sama dalam mempengaruhi variabel dependen atau adanya pengaruh langsung variabel independen (main effect) pada variabel dependen atau adanya interaksi antara variabel independen (interaction effect) dalam mempengaruhi variabel dependen. Jika hipotesis nol diterima bukan berarti hal ini salah, akan tetapi tidak ada justifikasi secara ilmiah untuk mengatakan di satu sisi benar dan di sisi lain salah namun terdapat alasan secara logika mengenai kebenarannya (Huck, 2005).

Selain itu analisis of variance dapat juga digunakan untuk memberikan ramalan mengenai seberapa besar relatif kontribusi sumber dalam model sebagai variabel independen untuk perbedaan di dalam variabel dependen (Belk, 1974a). Dengan berbagai argumen tersebut maka penelitian ini menggunakaan one anova yang berhubungan erat dengan pentingnya interaksi dari sumber-sumber utama (situasi, produk dan karakteristik individu) yang berpengaruh pada perilaku konsumen dalam membeli dan mengkonsumsi. Metode ini digunakan karena untuk menguji kategori situasi konsumsi, kategori produk makanan ringan dan karakteristik individu sebagai main effect dan sebagai interaction effect pada perilaku pembelian dan pengkonsumsian makanan ringan.

\section{HASIL DAN PEMBAHASAN}

Penelitian ini menemukan bahwa ada pengaruh langsung variabel situasi konsumsi dan karakteristik individu (usia, jenis kelamin, tingkat pendidikan) pada perilaku membeli dan mengkonsumsi. Pada level signifikansi 5\%, variabel situasi konsumsi memberikan hasil yang signifikan yaitu sebesar 0.009 sedangkan variabel karakteristik individu memberikan hasil yang signifikan untuk usia (0.024), jenis kelamin (0.003), dan tingkat pendidikan (0.005). Hal ni menunjukkan bahwa perbedaan situasi konsumsi dan karakteristik individu (usia, jenis kelamin, tingkat pendidikan) dapat mempengaruhi perilaku membeli dan mengkonsumsi. Penelitian ini juga menemukan bahwa tidak ada pengaruh langsung variabel produk makanan ringan pada perilaku membeli dan mengkonsumsi. Pada level signifikansi 5\%, variabel produk makanan ringan tidak memberikan hasil yang signifikan yaitu sebesar 0.871 . Hal ini menunjukkan bahwa perbedaan produk makanan ringan tidak mempengaruhi perilaku membeli dan mengkonsumsi.

Secara keseluruhan, hasil penelitian ini hampir seluruhnya tidak mendukung penelitian sebelumnya yang dilakukan oleh Belk (1974a). Hal ini disebabkan karena penelitian ini bersifat exploratory study dimana peneliti mencoba menggali atau mencari apakah situasi konsumsi, produk makanan ringan dan karakteristik individu (usia, jenis kelamin, tingkat pendidikan) mempengaruhi perilaku membeli dan mengkonsumsi dalam kondisi yang berbeda. Namun, dari hasil penelitian ini ada satu hal yang mendukung penelitian Belk (1974a) yaitu mengenai tidak ada interaksi antara situasi konsumsi, produk makanan ringan dan karakteristik indidvidu jika dipandang dari sudut tingkat pendidikan. 
Selain itu, penelitian ini juga tidak mendukung penelitian yang dilakukan oleh Goldsmith et. al., (1995) yang mana mengatakan bahwa faktor demografi kurang memberikan hasil yang signifikan pada perilaku. Penelitian ini menemukan bahwa karakteristik individu sebagai main effect yang menggunakan faktor demografi (usia, jenis kelamin, tingkat pendidikan) memberikan hasil yang signifikan pada perilaku membeli dan mengkonsumsi. Dengan kata lain, perbedaan karakteristik individu mempengaruhi perilaku membeli dan mengkonsumsi.

Tabel 3 Ringkasan Hasil Pengujian Keseluruhan Hipotesis

\begin{tabular}{|c|c|c|c|c|}
\hline HIPOTESIS & SIG & HO & HASIL & KETERANGAN \\
\hline \multicolumn{5}{|l|}{ Hipotesis 1} \\
\hline - Situasi*Produk & 0.105 & Diterima & $\begin{array}{c}\text { Tidak ada pengaruh } \\
\text { bersama }\end{array}$ & $\begin{array}{l}\text { Tidak mendukung penelitian Belk (1974) yang } \\
\text { mengatakan bahwa ada pengaruh bersama antara } \\
\text { situasi dan produk }\end{array}$ \\
\hline \multicolumn{5}{|r|}{ 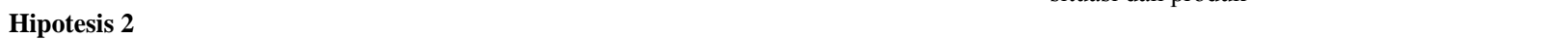 } \\
\hline - Situasi*Age & 0.042 & Ditolak & $\begin{array}{c}\text { Ada pengaruh } \\
\text { bersama }\end{array}$ & $\begin{array}{l}\text { Tidak mendukung penelitian Belk (1974) yang } \\
\text { mengatakan bahwa tidak ada pengaruh bersama } \\
\text { antara situasi dan individu }\end{array}$ \\
\hline - Situasi*Gender & 0.001 & Ditolak & $\begin{array}{l}\text { Ada pengaruh } \\
\text { bersama }\end{array}$ & $\begin{array}{l}\text { Tidak mendukung penelitian Belk (1974) yang } \\
\text { mengatakan bahwa tidak ada pengaruh bersama } \\
\text { antara situasi dan individu }\end{array}$ \\
\hline - Situasi*Education & 0.003 & Ditolak & $\begin{array}{c}\text { Ada pengaruh } \\
\text { bersama }\end{array}$ & $\begin{array}{l}\text { Tidak mendukung penelitian Belk (1974) yang } \\
\text { mengatakan bahwa tidak ada pengaruh bersama } \\
\text { antara situasi dan individu }\end{array}$ \\
\hline \multicolumn{5}{|l|}{ Hipotesis 3} \\
\hline - Produk*Age & 0.280 & Diterima & $\begin{array}{c}\text { Tidak ada pengaruh } \\
\text { bersama }\end{array}$ & $\begin{array}{l}\text { Tidak mendukung penelitian Belk (1974) yang } \\
\text { mengatakan bahwa ada pengaruh bersama antara } \\
\text { produk dan individu }\end{array}$ \\
\hline - Produk*Gender & 0.111 & Diterima & $\begin{array}{c}\text { Tidak ada pengaruh } \\
\text { bersama }\end{array}$ & $\begin{array}{l}\text { Tidak mendukung penelitian Belk (1974) yang } \\
\text { mengatakan bahwa ada pengaruh bersama antara } \\
\text { produk dan individu }\end{array}$ \\
\hline - Produk*Gender & 0.111 & Diterima & $\begin{array}{c}\text { Tidak ada pengaruh } \\
\text { bersama }\end{array}$ & $\begin{array}{l}\text { Tidak mendukung penelitian Belk (1974) yang } \\
\text { mengatakan bahwa ada pengaruh bersama antara } \\
\text { produk dan individu }\end{array}$ \\
\hline \multicolumn{5}{|l|}{ Hipotesis 4} \\
\hline - Situasi*Produk*Age & 0.029 & Ditolak & $\begin{array}{l}\text { Ada pengaruh } \\
\text { bersama }\end{array}$ & $\begin{array}{l}\text { Tidak mendukung penelitian Belk (1974) yang } \\
\text { mengatakan bahwa tidak ada pengaruh bersama } \\
\text { antara situasi, produk dan individu }\end{array}$ \\
\hline - Situasi*Produk*Gender & 0.044 & Ditolak & $\begin{array}{c}\text { Ada pengaruh } \\
\text { bersama }\end{array}$ & $\begin{array}{l}\text { Tidak mendukung penelitian Belk (1974) yang } \\
\text { mengatakan bahwa tidak ada pengaruh bersama } \\
\text { antara situasi, produk dan individu }\end{array}$ \\
\hline -Situasi*Produk*Education & 0.280 & Diterima & $\begin{array}{c}\text { Tidak ada pengaruh } \\
\text { bersama }\end{array}$ & $\begin{array}{l}\text { Mendukung penelitian Belk (1974) yang } \\
\text { mengatakan bahwa tidak ada pengaruh bersama } \\
\text { antara situasi, produk dan individu }\end{array}$ \\
\hline \multicolumn{5}{|l|}{ Main Effect } \\
\hline - Situasi & 0.009 & Ditolak & $\begin{array}{c}\text { Ada pengaruh } \\
\text { langsung }\end{array}$ & $\begin{array}{l}\text { Tidak mendukung penelitian Belk (1974) yang } \\
\text { mengatakan bahwa tidak ada pengaruh langsung } \\
\text { situasi }\end{array}$ \\
\hline - Produk & 0.871 & Diterima & $\begin{array}{c}\text { Tidak ada pengaruh } \\
\text { langsung }\end{array}$ & $\begin{array}{l}\text { Tidak mendukung penelitian Belk (1974) yang } \\
\text { mengatakan bahwa ada pengaruh langsung } \\
\text { produk }\end{array}$ \\
\hline - Usia & 0.024 & Ditolak & $\begin{array}{c}\text { Ada pengaruh } \\
\text { langsung }\end{array}$ & $\begin{array}{l}\text { Tidak mendukung penelitian Belk (1974) yang } \\
\text { mengatakan bahwa tidak ada pengaruh langsung } \\
\text { individu }\end{array}$ \\
\hline - Gender & 0.003 & Ditolak & $\begin{array}{l}\text { Ada pengaruh } \\
\text { langsung }\end{array}$ & $\begin{array}{l}\text { Tidak mendukung penelitian Belk (1974) yang } \\
\text { mengatakan bahwa tidak ada pengaruh langsung } \\
\text { individu }\end{array}$ \\
\hline - Education & 0.005 & Ditolak & $\begin{array}{l}\text { Adapengaruh } \\
\text { langsung }\end{array}$ & $\begin{array}{l}\text { Tidak mendukung penelitian Belk (1974) yang } \\
\text { mengatakan tidak ada pengaruh langsung } \\
\text { individu }\end{array}$ \\
\hline
\end{tabular}




\section{SIMPULAN}

Simpulan hasil pengujian hipotesis dalam penelitian ini yang diuji dengan menggunakan one way anova adalah bahwa variabel karakteristik individu (usia, jenis kelamin, tingkat pendidikan) yang mudah diamati, memberikan hasil yang signifikan pada perilaku membeli dan mengkonsumsi. Perbedaan karakteristik individu (usia, jenis kelamin, tingkat pendidikan) mempengaruhi perilaku membeli dan mengkonsumsi. Dengan kata lain, karakteristik individu (usia, jenis kelamin, tingkat pendidikan) merupakan maineffect atau pengaruh langsung pada perilaku membeli dan mengkonsumsi. Hasil penelitian ini juga menemukan bahwa variabel situasi sebagai main effect memberikan hasil yang signifikan pada perilaku membeli dan mengkonsumsi. Dengan kata lain perbedaan situasi konsumsi mempengaruhi perilaku membeli dan mengkonsumsi.

Penelitian ini juga menjelaskan bahwa interaksi antara situasi konsumsi dan karakteristik individu (usia, jenis kelamin, tingkat pendidikan) sebagai first order interaction effect memberikan hasil yang signifikan. Dengan kata lain, perbedaan antara situasi konsumsi dan karakteristik individu (usia, jenis kelamin, tingkat pendidikan) mempengaruhi perilaku membeli dan mengkonsumsi. Sedangkan pada second order interaction effect yaitu interaksi situasi konsumsi, produk makanan ringan dan karakteristik individu yang diwakili oleh usia dan jenis kelamin saja yang mempengaruhi perilaku membeli dan mengkonsumsi. Oleh karena itu, karakteristik individu sebagai stimulus configuration dari stimulus produk dan situasi, sehingga individu yang bertindak sebagai responden akan memberikan respon pada perilaku pembelian dan pengkonsumsian jika diinteraksikan dengan variabel situasi dan produk serta interaksi produk dan situasi agar dapat memberikan hasil yang signifikan pada perilaku konsumen. Akan tetapi, dasar pemilihan kategori karakteristik individu perlu dipertimbangkan untuk variabel produk tertentu dalam situasi tertentu pula.

Penelitian ini tidak mengembangkan situasi-situasi konsumsi untuk waktu dan tempat yang diobservasi sehingga terjadi ketidak-konsistenan antara prosedur metodologi yang digunakan dengan tujuan riset. Dengan kata lain, penelitian ini tidak melakukan pra survei untuk tujuan mengeksplorasi situasi-situasi yang umum terjadi pada saat melakukan pembelian dan pengkonsumsian makanan ringan sehingga pengelompokan dan pemberian nama pada faktor dari hasil exploratory factor analysis untuk variabel situasi konsumsi tidak cukup memadai.

Penelitian ini hanya menggunakan situasi internal yang umum digunakan oleh konsumen ketika membeli dan mengkonsumsi produk. Situasi internal yang digunakan oleh konsumen berupa situasi konsumsi yang berhubungan dengan pendefinisian tugas dimana konsumen membeli dan mengkonsumsi produk untuk kebutuhan dan keinginan tertentu. Jika dilihat dari variabel produk yang digunakan dalam penelitian ini, peneliti tidak membandingkan jenis produk yang digunakan. Penelitian hanya menggunakan satu jenis kategori produk makanan yaitu makanan ringan. Sedangkan variabel karakteristik individu yang digunakan hanya berdasarkan karakteristik individu yang mudah diamati seperti usia, jenis kelamin, tingkat pendidikan terakhir.

\section{DAFTAR PUSTAKA}

Arditya (2010). Analisa Pengaruh Faktor-Faktor Situasional Dalam Pengambilan Keputusan Beli Konsumen Terhadap Produk Yang Ditawarkan Melalui E-commerce. Skripsi. Fakultas Ekonomi, Universitas Gadjah Mada (tidak dipublikasikan).

Assael, H. (1998). Consumer Behavior. 6th ed. Cincinatti, OH: South Western College Publishing.

Baumgartner, H. (2002). Toward a Individuology of the Consumer. Journal of Consumer Research, 29: $286-292$. 
Belk, R. (1974a). An Exploratory Assessment of Situational Effect in Buyer Behavior. Journal of Marketing Research. 156-163.

. (1974b). Application and Analysis of The Behavioral Differential Inventory For Assessing Situasional Effects in Buyer Behavior. Advances In ConsumerResearch, 2(1): 370-380.

. (1975a). The Objective Situation as a Determinant of Consumer Behavior. Advances In Consumer Research, 2 (1): 427-437.

. (1975b). Situational Variables and Consumer Behavior. Journal of Consumer Research, 2: 157-164.

Broderic, A., Mueller, R. (2004). A Theoretical and Empirical Exegesis of The Involvement Construct: The Psychology of The Food Shopper. Journal of Marketing Theory and Practice, 97-108.

Cooper, D.R., Schindler, P.S. (2006). Bussiness Research Method, 8th ed. New York: Mc Graw Hill Irwin.

Crask, M., Fox, J.R., Stout, G.R. (1995). Research Marketing. Englewood Cliffs, New Jersey: Prentice Hall, Inc.

Csikszentmihalyi, M. (2000). The Cost and Benefits of Consuming. Journal of Consumer Research, 27: $267-278$.

Endler, N. S., Rosenstein, A. J. (1997). Evolution of the Individuity Construct in Marketing and Its Applicability to Contemporary Individuity Research. Journal of Consumer Psychology, 6(1): 55-66.

Fink, A. (2009). How To design Surveys. London: SAGE Publications.

Goldsmith, R. E., Freiden, J., Henderson. K. V. (1995). The Impact of Social Values on Food-related Attitudes. Journal of Product \& Brand Management, 4(4): 6-14.

Ghozali, I. (2001). Aplikasi analisis multivariat dengan program SPSS. Penerbit Universitas Diponegoro.

Hair, J. F., Anderson, R. E., Tatham, R. L., Black, W. C. (1998). Multivariate Data Analysis, 5th ed. Upper Saddle River, New Jersey: Prentice Hall, Inc.

Homburg, C., Giering, A. (2011). Individu Characteristics as Moderators of the Relationship Between Customer Satisfaction and Loyality-an Empirical Analysis. Psycology \& Marketing, 18(1): 43-66.

Huck, S. W. (2005). Reading Statistics and Research, 3th ed. New York: Addison Wesley Longman, Inc.

Kardes, F. R. (2002). Consumer Behavior and Managerial Decision Making, 2th ed. Upper Saddle River, New Jersey: Prentice Hall, Inc.

Kotler, P., Armstrong, G. (2012). Principles of Marketing. New Jersey: Prentice-Hall, Inc.

Loudon, L. D., Bitta, D. J. A. (2001). Consumer Behavior, 4th ed. New York: McGraw-Hill, Inc. 
Norusis, M. J. (2002). SPSS 11.0 Guide to Data Analysis. Upper Saddle River, New Jersey: Prentice Hall, Inc.

Pervin, L. A. (1989). Individus, Situations, Interactions: The History of a Controversy and a Discussion of Theoretical Models. Academy of Management Review, 14 (3):350-360.

Ratneshwar, S., Shocker, A. D., Cotte., J., Srivastava. R. K. (1999). Product, Person, and Purpose: Putting the Consumer Back Into Theories of Dynamic Market Behaviour. Journal of Strategic Marketing, 7: 191-208.

Russell, J. A., Mehrabian, A. (1976). Environmental Variabel in Consumer Research. Journal of Consumer Research, 3: 62-63.

Santoso, S. ( 2005). Pelatihan SPSS Statistik Parametrik. Jakarta: PT. Elex Media Komputindo.

Sekaran, U. (2003). Research Methods for Business: A Skill Building Approach, $4^{\text {th }}$ ed. New York: John Wiley \& Sons, Inc.

Solomon, R. M. (2002). Consumer Behavior, 5th ed. Upper Saddle River, New Jersey: Prentice Hall, Inc.

Srivastava, R. K. (1981). Usage-Situational Influences on Perceptions of Product Markets: Theoretical and Empirical Issue. Advances in Consumer Research, 8 (1): 106-111. 